\title{
PERFIS E ITINERÁRIOS DE MULHERES INTÉRPRETES DO MARANHÃO 12
}

\author{
Andressa de Carvalho Machado ${ }^{3}$ \\ Eliana Tavares dos Reis ${ }^{4}$
}

\begin{abstract}
RESUMO
Propomos neste artigo a apresentação de uma reflexão sobre as condições de afirmação de elites intelectuais no Maranhão, abordando as imbricações entre domínios culturais e políticos a partir da análise de mulheres que ocupam posições bem-alocadas como intérpretes da cultura no/do estado. São analisadas oito agentes que se destacam particularmente na elaboração e produção de bens simbólicos, ocupando cargos de gestão de políticas públicas e a direção de instituiç̃oes culturais, estando nos domínios da cultura maranhense a partir de diferentes meios de expressão: literatura (Arlete Nogueira Machado), artesanato (Déborah Baesse), artes plásticas (Rosilan Garrido), "patrimônio" (Kátia Santos Bogéa), culinária (Zelinda Lima), artes cênicas (Lenita Estrela de Sá), música (Rosa Reis) e "cultura popular" (Maria Michol Pinho de Carvalho). Tomando este universo como referência, buscamos mapear seu perfil social, cultural e profissional, bem como indicar pistas sobre os condicionantes de socialização e seus posicionamentos em relação à "cultura" do estado. Por esse intermédio, apreendemos ainda quais os recursos equivalentes ou distintivos que elas possuem em relação aos seus homólogos homens, como certas disposições sociais se refletem em determinadas modalidades ou posicionamentos por elas assumidos e que trunfos mobilizam nas disputas em torno da definição de "cultura" das quais elas participam, o que conduz a problematizar, com alguns limites, as "questões de gênero" que estruturam as inscrições e tomadas de posição dessas agentes. Tais aspectos nos permitiram uma compreensão inicial dos processos de definição das concepções de "cultura" no e do Maranhão abrangendo as condições de afirmação e legitimação dessas agentes, que numa combinação entre "vocação", "tradição", "heranças familiares", "títulos escolares" e laços de amizades, garantem seus lugares como porta-vozes e sua eficácia no trabalho de categorização do mundo social.
\end{abstract}

Palavras-chave: Elites. Cultura. Perfis. Mulheres.

\begin{abstract}
In this article, we propose to present a reflection on the conditions of affirmation of intellectual elites in Maranhão, approaching the overlap between cultural and political domains from the analysis of women who occupy positions well allocated as interpreters of the culture in the state. They are eight agents who stand out particularly in the elaboration and production of symbolic goods and occupying public policy management positions and direction of cultural institutions in the domains of the Maranhão culture from different means of expression: literature (Arlete Nogueira Machado), handicraft (Débora Baesse), visual arts (Rosilan Garrido), "heritage" (Kátia Santos Bogéa), culinary (Zelinda Lima), scenic arts (Lenita Estrela de Sá), music (Rosa Reis), and "popular culture" (Maria Michol Pinho de Carvalho). Taking this universe as a reference, we seek to map its social, cultural and professional profile, as well as to indicate clues about the conditioners of socialization and the positioning in relation to the "culture" of the state. Through this, we apprehend what equivalent or distinctive features they possess in relation to their male counterparts, how certain social dispositions are reflected in certain modalities or positions and what trumps they mobilize in the disputes around the definition of "culture" in which they participate, which leads to problematizing, with some limits, "gender issues" that structure the inscriptions and positions of these agents. These aspects allowed us an initial understanding of the processes of definition of the conceptions of "culture" in and of Maranhão covering the conditions of affirmation and legitimation of these agents, which in a combination between "vocation", "tradition", "family inheritances", "school titles" and ties of friendships, guarantee their places as spokespersons and their effectiveness in categorizing the social world.
\end{abstract}

Keywords: Elites. Culture. Profiles. Women.

\footnotetext{
${ }^{1}$ Submetido em: 30 de Setembro de 2017. Aprovado em: 15 de Outubro de 2017.

${ }^{2}$ DOI: http://dx.doi.org/10.5380/recp.v8i3.57152

${ }^{3}$ Mestranda do Programa de Pós-graduação em Ciências Sociais da Universidade Federal do Maranhão. Pesquisadora do Laboratório de Estudos sobre Elites Políticas e Culturais. Bolsista CAPES. E-mail: andressaac.carvalho@gmail.com.

${ }^{4}$ Doutora em Ciência Política pela Universidade Federal do Rio Grande do Sul (UFRGS). Professora e pesquisadora do Programa de Pós-graduação em Ciências Sociais da Universidade Federal do Maranhão (UFMA). Coordenadora do Laboratório de Estudos sobre Elites Políticas e Culturais (LEEPOC). Bolsista produtividade CNPq. E-mail: eliana1reis@terra.com.br.
} 


\begin{abstract}
RESUMEN
Proponemos en este artículo presentar una reflexión sobre las condiciones de afirmación de las élites intelectuales en Maranhão, abordando las imbricaciones entre dominios culturales y políticos a partir del análisis de mujeres que ocupan posiciones bien asignadas como intérpretes de la cultura en el/del estado. En el caso de la cultura maranhense, se trata de una serie de actividades que se destacan particularmente en la elaboración y producción de bienes simbólicos y ocupan cargos de gestión de políticas públicas y dirección de instituciones culturales en los ámbitos de la cultura maranhense a partir de diferentes medios de expresión: literatura (Arlete Nogueira Machado), artesanía (Débora) (Rosita Garrido), artes plásticas (Rosilan Garrido), "patrimonio" (Kátia Santos Bogéa), culinaria (Zelinda Lima), artes escénicas (Lenita Estrela de Sá), música (Rosa Reis), y "cultura popular" (Maria Michol Pinho de, Roble). Tomando este universo como referencia, buscamos mapear su perfil social, cultural y profesional, así como indicar pistas sobre los condicionantes de socialización y de los posicionamientos en relación a la "cultura" del estado. Por ese intermedio, aprehendemos aún cuáles son los recursos equivalentes o distintivos que poseen en relación a sus homólogos hombres, como ciertas disposiciones sociales se reflejan en determinadas modalidades o posicionamientos asumidos y que las ventajas movilizan en las disputas en torno a la definición de "cultura" en las quales ellas participan, lo que conduce a problematizar, con algunos límites, "cuestiones de género" que estructuran sus inscripciones y tomas de posición de esos agentes. Estos aspectos nos permitieron una comprensión inicial de los procesos de definición de las concepciones de "cultura" en y de Maranhão cubriendo las condiciones de afirmación y legitimación de esos agentes, que en una combinación entre "vocación", "tradición", "herencias familiares", "títulos escolares y lazos de amistad, garantizan sus lugares como portavoces y su eficacia en el trabajo de categorización del mundo social.
\end{abstract}

Palabras clave: Elites. Cultura. Perfiles. Mujeres.

\title{
1. INTRODUÇÃ̃O
}

O presente artigo analisa alguns condicionantes de afirmação, de localização e de tomada de posição de mulheres que atuam em domínios culturais no Maranhão. São oito agentes que atuam como produtoras de bens simbólicos, também ocupando posições de destaque como lideranças de diferentes meios de expressão: da literatura (Arlete Nogueira Machado), do artesanato (Déborah Baesse), das artes plásticas (Rosilan Garrido), do "patrimônio" (Kátia Santos Bógea), da culinária (Zelinda Lima), das artes cênicas (Lenita Estrela de Sá), da música (Rosa Reis) e da "cultura popular" (Maria Michol Pinho de Carvalho).

Essas mulheres foram identificadas na pesquisa intitulada "O trabalho de construção de um 'perfil artístico e cultural do Maranhão"', que investigou um conjunto de porta-vozes da cultura no estado (REIS, 2014a). Entre vários homens, elas apareceram com notabilidade nas áreas citadas, instigando a busca pelas características, pelos atributos, pelas práticas e pelas representações que estão na base do destaque que elas conquistaram, ou pelos limites das suas inscrições em relação a esse universo mais amplo.

Nossa proposta de investigação está inserida na agenda de estudos do Laboratório de Estudos sobre Elites Políticas e Culturais (LEEPOC), priorizando o exame dos perfis sociais dessas agentes, de suas práticas políticas, das suas produções literárias e das suas modalidades de inserção nos domínios culturais, além de outros aspectos que, 
comparativamente àqueles verificados no universo mais amplo, permitirão observar os critérios de consagração de "mulheres da cultura maranhense".

Um dos projetos mais amplos desenvolvidos no laboratório é intitulado "Intérpretes do Maranhão: trajetórias políticas e intelectuais de porta-vozes da 'cultura', da 'política' e da 'sociedade'". Neste, a atenção é direcionada às características e estratégias de afirmação de agentes reconhecidos como autorizados a descrever, defender e representar a cultura maranhense nas suas diferentes dimensões. Como resultado preliminar, este estudo trouxe mais pistas sobre a posição de mulheres que conquistam posições como intérpretes/porta-vozes da "cultura popular", atuando em distintos segmentos. É seguindo nesta linha de investigação que procuramos compreender os processos de disputa e de legitimação em torno da definição de "cultura" dos quais elas participam, afirmando-se como agentes com autoridade legítima para falar em nome da "cultura maranhense" e produzir representações sobre o que ela é ou deveria ser.

Nosso ponto de partida é o modelo analítico de Pierre Bourdieu, construído a partir da análise do processo histórico e social de constituição de múltiplos campos, que formam um espaço complexo de microcosmos dotados de lógicas e leis próprias, uns relativamente autônomos em relação aos outros e engendrando o macrocosmo social. Especificamente sobre a noção de campo, é preciso considerar que "os processos de autonomização, percebidos em dinâmicas ocidentais, não necessariamente resultaram na definição, em dinâmicas periféricas, de delimitações como 'ordem', 'classe', 'campo' ou 'esfera' de uma vez por todas bem definidas" (CORADINI; REIS, 2012, p. 11). As pesquisas realizadas no LEEPOC seguem este caminho de problematização da aplicação de conceitos e esquemas analíticos de forma direta e irrefletida na "realidade brasileira", sem levar em conta as diferenças de configuração marcadas por intersecções contundentes entre domínios e lógicas sociais. Adotamos as noções de domínios e multinotabilidades, que nos permitem considerar as

[...] imbricações entre domínios sociais modelados em processos de politização em distintos níveis, que, a um só tempo, produzem e são produzidos nos intercruzamentos de lógicas e registros de atuação acionados (relacional e concorrencialmente) por agentes portadores de certas propriedades sociais. Do mesmo modo, é possível detectar múltiplos recursos (materiais e simbólicos), mais ou menos institucionalizados, personificados por agentes que conquistam notoriedade e legitimidade para definir e agir sobre o mundo social. Compreendendo como, por esse intermédio, alcançam posições (de) notáveis nas hierarquias de domínios específicos e na do espaço social mais amplo, ou seja, desfrutam de multinotabilidades. (GRIL; REIS, 2016a, p. 23, grifos dos autores). 
Nesse sentido, para compreender os condicionantes de afirmação das agentes estudadas, procuramos examinar as características sociais e os lugares de atuação das agentes e, também, a sua produção cultural e suas oportunidades de ocupação de cargos administrativos. Como elas atuam em áreas diversificadas, optamos por considerar, neste momento, em especial as inserções políticas e a produção escrita detectadas, pois são trunfos comuns a todas elas e uma importante mostra da proeminência que elas conquistaram, demonstrando a convergência de lógicas de distinção em diferentes âmbitos sociais.

A atenção dada à produção escrita está baseada em outros achados de pesquisa que demonstraram a relevância desse tipo de investimento nas multinotabilidades políticas e intelectuais conquistadas por determinados/as agentes (GRILL; REIS, 2012). Mais especificamente, propomos tratar das imbricações entre os domínios políticos e culturais, observando as interferências das lógicas políticas (no sentido amplo do termo) e de outros princípios de classificação do mundo social no reconhecimento intelectual conquistado por mulheres "da cultura".

O interesse pelos atributos e caraterísticas sociais das agentes que se destacam como porta-vozes da "cultura", escrevendo textos e ocupando cargos administrativos, permite examinar as condições sociais e políticas da eficácia simbólica das representações que elas compartilham ou tentam impor, colocando-se em pauta as disputas pelos princípios de visão e di-visão do mundo, ou as "lutas de classificação" (BOURDIEU, 1996). Elas se inscrevem nas disputas entre princípios de classificação acerca das concepções de "cultura" e das demais noções que se agregam a ela, incluindo a formulação de identidades regionais, com a constituição de fronteiras resguardadas de sentidos de pertencimento.

O móvel de todas essas lutas é o poder de impor uma visão do mundo social através dos princípios de di-visão que, tão logo se impõem ao conjunto de um grupo, estabelecem o sentido e o consenso sobre o sentido, em particular sobre a identidade e a unidade do grupo que está na raiz da realidade e da unidade e da identidade do grupo. (BOURDIEU, 1996, p.108)

Num espaço mais amplo do poder, essas agentes se localizam em disputas em torno das formas de percepção e imposição do mundo social. Dotadas de certas propriedades sociais que garantem a elas a legitimidade necessária para a produção de representações e interpretações do mundo social, elas participam da produção e reprodução da objetividade (emblemas, bandeiras, sotaques) e das representações mentais que delimitam as fronteiras místicas e fluídas capazes de, na sua eficácia simbólica, assegurar diferenças (BOURDIEU, 2008). 
Não tão distante da prática das ações políticas, admitindo-a como toda ação "que tem como objetivo produzir e impor representações (mentais, verbais, gráficas ou teatrais) do mundo social capazes de agir sobre esse mundo social, agindo sobre as representações ao seu respeito" (BOURDIEU, 2008), a atuação dessas agentes nesse processo de afirmação e definição da "cultura" no e do Maranhão se inscreve nesse jogo de prescrever e descrever o mundo social por meio de suas concepções de "cultura" constantemente em disputa.

Sendo assim, não só a "diferença cultural”, mas também as distintas definições de "cultura" são "produtos de uma dialética histórica da diferenciação cumulativa" (BOURDIEU, 2008), dotadas de arbitrariedade - são construções instauradas na realidade, sobre a força e eficácia de discursos performativos, que sacralizam fronteiras mágicas do mesmo modo que dizem respeito à unidade, ao consenso e à identidade de grupos pela crença e legitimidade daquele(s) que têm fala autorizada. Aquele que enuncia, o autor é o porta-voz garantido não só pelo reconhecimento do grupo, mas também por compartilhar com ele um sentido de identificação, sentido este que, num processo de mútua existência, garante-lhe a fala e o discurso autorizado, além da crença e da partilha de propriedades sociais (sejam elas econômicas ou culturais) que embasam o sentimento de pertença ao grupo (BOURDIEU, 2008).

A análise da configuração maranhense demonstra que três aspectos se destacam no processo de afirmação de porta-vozes e domínios em torno da problemática legítima ligada à definição da "cultura maranhense": a construção e a incorporação da "identidade", da "memória" e da "tradição".

Esses elementos são construídos e ressignificados nas relações vividas e nas leituras oferecidas pelas agentes em distintos momentos históricos. De acordo com esse raciocínio, o “porta-voz" alinha-se à figura de um membro identificador (PIZZORNO, 1988), uma vez que a existência do grupo reside na sua própria existência, na lealdade e na crença que não só o grupo deposita nesse jogo de representatividade, mas que o próprio porta-voz deposita na causa legítima e digna defendida pelo grupo.

Como ressaltam Brubaker e Cooper (2013), a identidade, na sua fluidez e flexibilidade, é passível de diversos "usos" e, no gerar do sentimento de unidade, "fundamenta ações sociais ou políticas". Ter uma identidade, seja ela coletiva ou individual, é uma condição para a existência social. Portanto, tal identidade é compreendida como algo a ser valorizado e cultivado, mas que deve ser entendido como "o produto infinito de discursos múltiplos, variável e fragmentado" (BRUBAKER; COOPER, 2013).

As identificações que fundamentam a construção de uma identidade comum, no mesmo movimento, produzem, fundamentam e transmitem elementos que passam a residir na 
"memória" e a fabricar "a tradição". Elas são flexíveis e mobilizadas para o trabalho de enquadramento, seleção e reconversão de memórias individuais em coletivas (POLLAK, 1992), que buscam uma origem comum e mobilizam-na para ancorar pertencimentos e instituir diferenças "irredutíveis":

\begin{abstract}
A memória, essa operação coletiva dos acontecimentos e das interpretações do passado que se quer salvaguardar, se integra, como vimos, em tentativas mais ou menos conscientes de definir e de reforçar sentimentos de pertencimento e fronteiras sociais entre coletividades de tamanhos diferentes: partidos, sindicatos, igrejas, aldeias, regiões, clãs, famílias, nações etc. A referência ao passado serve para manter a coesão dos grupos, e das instituições que compõem uma sociedade, para definir seu lugar respectivo, sua complementariedade, mas também as oposições irredutíveis. (POLLAK, 1989, p. 3)
\end{abstract}

Nessa tentativa de "interpretar um passado que se quer salvaguardar", dá-se a invenção da "tradição" e as possibilidades de seus usos. A ideia de herança e continuidade de algo do passado como justificativa de um presente vivo não é natural nem dada, mas igualmente fruto de versões em disputa da "mensagem cultural" que interpela "todos aqueles [e aquelas] que a enunciam e a reproduzem no dia-a-dia, [oferecendo-lhes] o meio de afirmar sua diferença e, por isso mesmo, de assentar sua autoridade" (LENCLUD, 2013, p. 158).

Nesse caso, a ideia de "cultura" e a de "região" se confundem em torno da definição de uma identidade regional, e o "culto" da região é particularmente oportunizado a partir de instâncias do domínio cultural nas quais os e as agentes investem (não de forma cínica). São lugares de produção e manutenção de interpretações do passado (produção de "memórias"), na consagração das suas características típicas, nas marcas que devem acompanhar os novos aderentes e, por esse intermédio, os seus porta-vozes autorizados.

Essa dinâmica é, portanto, marcada por intersecções entre domínios e mescla de lógicas políticas, culturais e religiosas, o que condicionam e é condicionado pelo múltiplo investimento das agentes em distintos mecanismos de reconhecimento, não só como a obtenção de títulos e certificações institucionais, consagração pessoal, dos interconhecimentos e das afinidades morais. Como Grill (2014) já apontava no que diz respeito ao domínio político, os domínios culturais também comportam princípios personificados de legitimação das suas lideranças e têm como característica preponderante uma espécie de reprodução familiar, que justamente pauta a sua legitimidade nas ideias de "tradição" e "memória". Observamos que o maior ou menor destaque adquirido pelas mulheres nesse sentido está diretamente relacionado ao lugar das suas famílias e familiares no espaço cultural do estado e, mais particularmente, na posição que elas ocupam no âmbito familiar. $\mathrm{O}$ reconhecimento que elas conquistam é o 
reconhecimento que está disponível para tal no universo de lutas (também de gênero) em questão.

A consideração dessas dimensões de análise permite, com certos limites, acompanhar as discussões presentes nas teorias feministas ou de gênero, principalmente as reflexões de Joan Scott (1995), que propõe a ruptura com perspectivas que essencializam as diferenças entre mulheres e homens ou que homogeneízam a categoria "mulher" com base em um determinismo biológico e na perspectiva estática das características, sensibilidades e papeis sociais dos sexos. Mais proveitoso que a diferença binária entre "macho" e "fêmea", segundo a autora, é seguir uma perspectiva da diferença múltipla, isto é, de uma multiplicidade de indicadores (origem de classe, raça/etnia, geração, comportamento, caráter, desejo, subjetividade, sexualidade, experiência histórica, etc.) que definam a diversidade de concepções e práticas em torno dessas categorias.

A análise de Norbert Elias (1987) quanto ao equilíbrio da balança do poder entre os sexos é instável e, portanto, é preciso considerar os aspectos específicos das configurações de interdependências e de lutas que estamos estudando para conseguir apreender as lógicas e mecanismos de dominação em pauta. $\mathrm{O}$ autor demonstrou que "uma das condições para diminuir a desigualdade entre homens e mulheres em uma sociedade foi o crescimento de uma organização de Estado, particularmente de suas instituições jurídicas e policiais, capaz de impedir os homens de usar sua força ou influência para impor sua vontade sobre as mulheres" (ELIAS, 1987, p. 308).

Como indicou Ana Paula Simioni (2008, p. 23), diante da "vala de esquecimento coletivo" que geralmente atinge a atuação das mulheres, é preciso investigar o espaço dos possíveis, no sentido dado por Bourdieu (2002), para entender as condições e os condicionantes que funcionam no destaque que algumas delas adquirem, em dinâmicas mais ou menos favoráveis. Sendo a presença feminina geralmente rara em segmentos de elites, é preciso compreender os mecanismos de reprodução da dominação masculina (BOURDIEU, 2002) e das bases do reconhecimento que conquistam (REIS, 2014c; SIMIONI, 2008).

Assim, essas agentes atuam fortemente nesse processo de manutenção e construção de fronteiras ("cultura", "identidade regional", "memória" e "tradição"), combinando, ao longo se suas trajetórias, elementos e propriedades de legitimação específicos desse universo de lutas objetivas e simbólicas. 


\section{PERFIS BIOGRÁFICOS DAS PORTA-VOZES DA CULTURA}

Para tentar operacionalizar as dimensões de análise que discutimos até aqui, neste primeiro momento da pesquisa em andamento reunimos dados a partir de diferentes fontes documentais e de sites de internet (matérias disponibilizadas em páginas eletrônicas de jornais e, sobretudo, na página do Currículo Lattes), sistematizados em quadros sinópticos. Porém, a escassez de informações disponíveis, principalmente biográficas, limitou as possibilidades de análise e de demonstração mais exata do perfil social e dos investimentos culturais das agentes. No entanto, os perfis biográficos esboçados permitem observar algumas regularidades e discrepâncias nas características sociográficas das agentes, que serão melhor exploradas com a realização de entrevistas em profundidade. Pretendemos, com essas entrevistas, somadas aos dados coletados e ao estudo da bibliografia temática pertinente e com o suporte do conjunto de pesquisas que vêm sendo realizadas, investir na construção das trajetórias das "intérpretes" do Maranhão, localizando-as ao longo do tempo e considerando as "relações objetivas que [as] uniram [...] ao conjunto dos outros agentes envolvidos" num "mesmo espaço dos possíveis" (BOURDIEU, 1996, p. 190). Segundo Bourdieu, esta é

[...] a condição de qualquer avaliação rigorosa do que podemos chamar de superfície social, como descrição rigorosa da personalidade designada pelo nome próprio, isto é, o conjunto das posições simultaneamente ocupadas num dado momento por uma individualidade biológica socialmente instituída e que age como suporte de um conjunto de atributos e atribuições que lhe permitem intervir como agente eficiente em diferentes campos.

Iniciamos, então, com a caracterização dos perfis sociais das agentes. Das oito mulheres, quatro nasceram na capital do estado, duas no interior do Maranhão e duas em outros estados do Nordeste (Ceará e Sergipe). Suas origens sociais estão nas camadas médias e baixas da sociedade (as profissões dos pais localizadas foram: comerciante, ferroviário, marceneiro e teatrólogo). Seus pais, maridos e filhos têm atuação em expressões da "cultura maranhense" (teatro, dança, bumba-boi, "cultura popular", literatura, etc.)

Deve-se destacar, sobretudo, os dados biográficos de Zelinda Lima e Rosa Reis, para demonstrar a importância da inserção recorrente dos seus familiares em domínios culturais:

- Zelinda Lima nasceu em 27 de novembro de 1926, em São Luís, filha de um comerciante. Ela foi casada com Carlos Lima, um comerciário que se tornou concursado pelo Banco do Brasil (1948-1976). Ele se apresenta (observado em distintas 
fontes) como ator e teleator e folclorista autodidata. Carlos Lima também é autor de vários livros e membro da Academia Maranhense de Letras. Zelinda foi educada em casa durante muito tempo, uma "educação aos modos franceses" (LIMA, 2006). Depois, cursou o ensino médio no colégio Santa Teresa (então uma escola para "moças de elite") e, em 1998, escreveu os seguintes livros: Considerações sobre a culinária maranhense (1977); Subsídios para a história do turismo no Maranhão (1982); Pecados da Gula: comeres e beberes das gentes do Maranhão (1998); e Rezas, benzimentos e orações, a fé do povo (2006); Perfis de Cultura Popular: mestres, pesquisadores e incentivadores da cultura popular maranhense (2015). Ocupou diversos cargos ligados ao turismo, no Departamento de Turismo de Estado e na Maratur. Neste último órgão, foi diretora de eventos e produção, entre 1976 e 1979 e, em 1983, foi presidente. Além disso, foi diretora do Centro de Criatividade Odylo Vieira Filho e do Centro de Cultura Popular Domingos Vieira Filho e colaboradora do Museu Histórico e Artístico do Maranhão. O gosto pela "cultura popular" teria acontecido por intermédio da avó e do pai, que, sendo um grande comerciante, cultivava as suas relações com a clientela e patrocinava diretamente, em seu estabelecimento, danças folclóricas, tambor de crioula e bumba meu boi. Zelinda atribui a estes fatos a sua vivência e inserção no cenário da “cultura maranhense". Das suas produções em um modesto ateliê na sua casa viria a influência do artesanato ao longo da sua vida, e o interesse pela culinária teria sido decorrente da participação na preparação dos "pratos típicos" na infância, procurando entender os cardápios de acordo com as ocasiões, que, para ela, dizem muito sobre as manifestações da cultura do povo. Zelinda teve sete filhos, entre eles Déborah Baesse, que também consta entre as mulheres aqui estudadas (ver perfil adiante).

- Rosa Reis nasceu em São Luís e é cantora, atriz e dançarina. Foi casada com Nelson Brito até o ano de 2009, quando este veio a falecer. Ele, formado em comunicação social com especialização em jornalismo, era um renomado ator e diretor de teatro maranhense. Chegou a ser secretário da Associação Brasileira de Teatro de Bonecos (1981-1982); tesoureiro e diretor regional da Confederação Nacional de Teatro Amador (1984-1989); presidente da Federação de Teatro Amador do Maranhão (1984-1985; 1989-1990); e presidente da Fundação Municipal de Cultura, antes de sua morte (20012002). Ao lado dele e de Dona Teté (conhecida pela atuação na dança folclórica maranhense, principalmente no chamado "cacuriá", e tida como sua "mãe de consideração"), Rosa Reis coordenava o Laborarte (Laboratório de Expressões 
Artísticas) - entidade cultural que trabalha há 43 anos com "cultura popular" do Maranhão. Atualmente, Rosa assumiu a Coordenadoria Geral do "grupo". Rosa Reis e Nelson Brito tiveram três filhas, todas elas fortemente ligadas ao Laborarte e atuantes como "artistas populares", cantoras, bailarinas, coreógrafas e produtoras culturais.

Considerando os investimentos das agentes em títulos escolares, produções escritas e inserções culturais de um modo geral, destacamos que entre elas apenas duas não chegaram à educação superior (as duas citadas acima). As demais investiram em pós-graduações e em carreiras acadêmicas. Os cursos superiores frequentados foram: Filosofia; História; Desenho e Artes Plásticas; Letras e Direito; Serviço Social; e Pedagogia. As pós-graduações foram: mestrado em Filosofia Contemporânea (PUC/RJ); especialização em Historiografia Regional e Nacional, especialização em Metodologia da Pesquisa Científica; mestrado em Artes Plásticas (USP); especialização em Linguística Aplicada ao Ensino de Língua Materna e Estrangeira e mestrado em Cultura Popular; especialização em Política Social e Educacional e mestrado em Educação; especialização em Psicopedagogia; e especialização em Supervisão Educacional. Quanto às suas inserções em instâncias culturais, destacamos a atuação das agentes na Superintendência do Instituto do Patrimônio Histórico e Artístico Nacional (Iphan), no Laboratório de Expressões Artísticas (Laborarte) e na Comissão Maranhense de Folclore (CMF). A metade delas é ou foi professora universitária, e somente Rosa Reis não publicou nenhum livro ao longo da vida (considerando os títulos localizados, elas publicaram, em média, três livros cada).

Destacam-se os dois casos abaixo como exemplares:

- Arlete Nogueira Machado nasceu em 5 de setembro de 1936, em Cantanhede, interior do Maranhão. De origem humilde, é filha de um ferroviário. Sua mãe chegou a escrever poemas e crônicas assinando com o pseudônimo de Márcia Queiroz. Arlete se casou com Nauro Diniz Machado, poeta, considerado um expoente da literatura brasileira, que ocupou cargos no Detran, no Emater e na Secretaria do Estado do Maranhão. O filho do casal possui graduação incompleta em filosofia, mas é empresário e cineasta, responsável pela administração do Cine Praia Grande e do Cine Lume, influenciando diretamente no cenário cinematográfico maranhense. A escritora cursou o ensino médio no Liceu Maranhense (principal escola pública do estado), graduou-se em filosofia pela Universidade Federal do Maranhão e adquiriu o título de mestre em 
filosofia contemporânea pela Pontifícia Universidade Católica do Rio de Janeiro (PUC/RJ). Lecionou e se aposentou como professora da Universidade Federal do Maranhão. Ela foi a primeira Secretária da Cultura do estado e dirigiu o Teatro Arthur Azevedo. Além disso, como escritora, publicou vários livros: A parede (romance; edições: 1961, 1993, 1998); Cartas da paixão (ensaios filosóficos; edições: 1969, 1998); Compasso binário (romance; edições: 1972, 1998); Canção das horas úmidas (poesia; 1975); Litania da Velha (poema; edições: 1995, 1997, 1999, 2002); Contos inocentes (edições: 2000, 2001); e Trabalho Manual (Imago Editora, Rio de Janeiro, 1998), uma publicação resultante de um convênio entre a Biblioteca Nacional e a Universidade de Mogi das Cruzes. Desde o falecimento de Nauro Machado, no final do ano de 2015, Arlete tem se dedicado à organização das suas "memórias", com a provável publicação de escritos do autor, além de ter a intenção de inaugurar um instituto ou ONG que abrace causas socioculturais e que se localizará na antiga casa do casal, no centro de São Luís.

- Lenita Estrela de Sá nasceu em 15 de dezembro de 1961, em São Luís. Romancista, contista, poeta, dramaturga e roteirista, ela é uma dentre os onze filhos de Cecílio Sá, marceneiro e teatrólogo, responsável pela criação do Teatro Amador no Maranhão e de diversas companhias de teatro (em 2001 foi criado o Memorial Cecílio Sá, com fotos, jornais, folhetos, cartazes, escritos e instrumentos usados por ele). Formada em Letras e Direito, Lenita é pós-graduada em Linguística Aplicada ao Ensino de Língua Materna e Estrangeira. É autora dos livros A Filha do Pai Francisco (1995); Reflexos (1979); No Palco da Paixão — Cecílio de Sá 50 Anos (1988); A Lagartixa Crise-Crise (2005); e Cinderela de Berlim e outros contos (2010). Também participou das seguintes antologias: Antologia Guarnicê (Edições Guarnicê, 1984); Novos Poetas Do Maranhão (São Luís, UFMA, 1988); As Aves que Aqui Gorjeiam — Vozes Femininas na Poesia Maranhense (organizada por Clóvis Ramos, São Luís, Sioge, 1993); Circuito de Poesia Maranhense (Ceuma, 1995); Dicionário Crítico de Escritoras Brasileiras (organizado por Nelly Novaes Coelho, São Paulo, Escritura Editora, 2002). As peças teatrais, A Filha de Pai Francisco e Ana do Maranhão têm sido objeto de monografias de graduação, respectivamente, nos cursos de Letras da Universidade Estadual do Maranhão (UEMA) e da Universidade Federal do Maranhão (UFMA). Lenita de Sá militou no Sindicato Brasileiro de Autores Teatrais (SBAT), nos Sindicatos de Escritores do Rio 
de Janeiro (SERJ) e na União Brasileira de Escritores (UBE) (Disponível em: http://estreladesa.com.br/, acessado em : 07.04.2017).

Por último, ressaltamos a vinculação das agentes a domínios políticos, militantes e administrativos, sempre com referência à dimensão cultural. As atuações encontradas foram: diretora de órgãos de turismo já extintos, como o Departamento Estadual de Turismo, do governo de José Sarney (1966-1970) e a Maratur (Empresa Maranhense de Turismo), em diferentes gestões do governo do estado; componente do Programa de Municipalização da Cultura, subsecretária de Cultura, chefe da Assessoria Técnica de Assuntos Culturais do Governo do Maranhão, assessora da Escola de Música do Estado do Maranhão, superintendente de Cultura Popular da Secretaria de Cultura do Maranhão; secretária Municipal da Criança e Assistência Social do município de São Luís, presidente do Instituto de Cidadania Empresarial do Maranhão; participante do Sindicato Brasileiro de Autores Teatrais, dos Sindicatos de Escritores do Rio de Janeiro, da União Brasileira de Escritores; entre outros.

Seguem as biografias de duas agentes de gerações diferentes, porém com bases semelhantes de ocupação de cargos administrativos relacionados à cultura:

- Nascida em Fortaleza (Ceará) em 1949, Maria Michol Pinho de Carvalho é graduada em Serviço Social (UFMA), com mestrado em Comunicação (UFRJ), especialização em Política Social e Educacional e cursos de aperfeiçoamento em Cultura Brasileira e Maranhense e em Pesquisa Cultural. Atuou como membro do Programa de Municipalização da Cultura, foi subsecretária de Cultura, chefe da Assessoria Técnica em Assuntos Culturais vinculada ao Governo do Maranhão, prestou também assessoria à Escola de Música do Estado do Maranhão e foi superintendente de Cultura Popular da Secretaria de Cultura do Maranhão (cargos ocupados desde a década de 1980, nos governos do estado, com o apoio da "família Sarney”). Também foi diretora do Centro de Cultura Popular Domingos Vieira Filho e, de 1995 até a sua morte, presidiu a Comissão Maranhense de Folclore. Em 2009, assumiu a coordenação da equipe do Inventário de Referências Culturais dos Blocos Tradicionais (INRC), visando à obtenção do título de Patrimônio Imaterial do Brasil. Compôs o grupo de pesquisa sobre “Cultura Popular" cadastrado no CNPq/UEMA e, na apresentação do seu currículo lattes, declara-se com "experiência na área de Antropologia, com ênfase em Folclore, atuando principalmente nos seguintes temas: cultura popular, folclore e memória oral" 
(Disponível em: http://lattes.cnpq.br/6228997272896621). Organizou os seis volumes de "Memória de velhos: depoimentos — uma contribuição à memória oral da cultura popular maranhense", bem como publicou "Matracas que desafiam o tempo: é o bumbaboi do Maranhão — um estudo da tradição/modernidade na cultura popular" (1995), além de outros textos.

- Déborah Baesse é filha de Carlos Lima e Zelinda Lima, ambos considerados "portavozes da cultura popular maranhense". Os três fazem parte da Comissão Maranhense de Folclore. Déborah se formou em Pedagogia na UFMA, realizou especialização em Psicopedagogia e Supervisão Educacional na PUC/MG, mestrado em Educação na Universidade Estadual do Ceará, mestrado profissional em Pedagogia Professional no Instituto Superior Pedagógico para Educação Tecnica y Profesional, especialização em Psicopedagogia no Instituto Sedes Sapientiae e especialização em Supervisão Educacional, e está com o doutorado em Ciências Médicas em andamento, na UERJ (Disponível em: http://lattes.cnpq.br/7021918007271014). Ela ocupou o posto de presidente do Instituto de Cidadania Empresarial do Maranhão (ICE-MA), cargo administrativo na UNASUS/UFMS e participou do grupo de pesquisa Tecnologia e Inovação em Educação na Saúde, tendo sua gestão interrompida (por incompatibilidade de funções) para ser Secretária Municipal da Criança e Assistência Social de São Luís. Atualmente é professora do Departamento de Educação da UFMA e fala em nome da causa da infância e do adolescente. Fundou o Centro Educacional Colmeia e o Instituto Zeca (ONG de consagração que leva este nome devido à junção de Zelinda e Carlos). Também se dedica a definir o "artesanato maranhense", inclusive com publicações sobre o assunto: Artesanato: perfil cultural do Maranhão (São Luís, Amarte, 2006); e O saber que se tece na renda (publicado no livro de Isaurina de Azevedo Nuves, "Olhar, memória e reflexões sobre a gente do maranhão"; São Luís,

Comissão Maranhense de Folclore, 2003). Déborah Baesse é casada com um empresário e tem dois filhos.

\section{DISPOSIÇÕES E POSICIONAMENTOS SOBRE A “CULTURA”: UMA QUESTÃO DE GÊNERO?}

As oito agentes em questão estão inscritas no universo cultural do Maranhão e expressam a reconfiguração da "cultura" no estado, que, da reafirmação de padrões europeus, 
passa a um modelo de exaltação da "cultura popular", principalmente a partir das décadas de 1960, 1970 e 1980 (REIS, 2014b).

Atentamos para a adjetivação e definição da categoria "popular" e para a ênfase que assume nesse universo de disputa. O "popular", em relação ao "erudito", garante um princípio de hierarquização do espaço social e do domínio cultural, pensando-se a relação de produção desse domínio e dos agentes que o constituem (BOURDIEU, 2004). Além disso, para que se fale em nome do "povo" e para o "povo", torna-se um recurso de disputa híbrido, passível de ser utilizado em diversos domínios, sem um sentido preciso - muito pelo contrário, com um sentido abstrato - , mas que pode garantir o reforço da legitimidade desfrutada por seu portavoz. Contudo, os usos do "povo" ou do "popular" podem garantir também diferenciações entre seus “porta-vozes”. No trabalho sobre panteões de consagração dos perfis de cultura popular, foi evidenciado:

[...] o corte entre as "personalidades" que foram privilegiadas pelo desempenho de "atividades" específicas consideradas expressões da "cultura popular" ("artesanato", "bumba-meu-boi", "carnaval”...) e aquelas que foram destacadas, não por exercer uma ou outra atividade, mas por "pesquisar" ou "incentivar" a "cultura popular". Objeto e sujeito encontram-se sob o mesmo termo de síntese. Porém é explicitamente diferenciada tanto a relação com a "cultura" como o tipo de "cultura" que representam. (GRILL; REIS, 2016, p. 24).

Para as agentes em questão, essa aproximação pode ser percebida pelas escolhas dos "títulos" de seus escritos, como se vê nos próprios depoimentos de algumas delas. No caso de Michol de Carvalho e Déborah Basse a ênfase é verificada nos seus escritos. Da primeira, destacamos "Memórias de velhos: depoimentos — uma contribuição à memória oral da cultura popular maranhense" e "Matracas que desafinam o tempo: é o bumba-boi do Maranhão um estudo de tradição/modernidade na cultura popular", e da segunda temos "O saber que se tece na renda", "Práticas culturais e cotidiano: folclore, educação e cidadania" e "As "cenas enunciativas' das toadas dos sotaques de zabumba, de matraca e de orquestra do bumba-meuboi do Maranhão". Já no caso de Zelinda Lima, podemos realçar seus posicionamentos acerca da "cultura popular" e do "folclore" em depoimentos como o que segue:

Hoje se discute muito essa coisa das inovações, mudanças e interferências na cultura popular. Eu acho que tanto o folclore como o artesanato, tudo o que vem do povo pode ser modificado, para mais ou para menos, ou mesmo, acabar. O povo tem esse direito. Quando ele acabar é porque sente que não tem mais sentido. (LIMA, 2006, p.300). 
Rosa Reis dança (bumba meu boi, cacuriá, dança do coco, tambor de crioula, etc.) e canta (interpreta compositores vinculados à música popular, como Ubiratan Souza, Erivaldo Gomes, César Teixeira e Seu Donato) a “cultura popular”, colocando-se como expressão direta (o que inclui origem, estilo de vida, forma de vestir e de se apresentar) do que seria essa cultura.

Para Arlete Nogueira e Lenita de Sá, a apropriação do "popular" é menos direta. A primeira é casada com um poeta e estudioso da cultura popular e oferece, por exemplo, em "Litania da Velha", 32 versos de um poema a aspectos que retratam o cotidiano, especificamente o de uma senhora cuja vida humilde (era uma mendiga) se dá nas ruas de São Luís e, a partir disso, descreve casarões, a arquitetura, bairros e outros aspectos que delineiam a parte "velha" da cidade e a "litania da velha", sendo assim feito um trabalho de memória. Porém, a análise desta obra precisa ser aprofundada. A segunda, em seu último livro lançado, “Catarina Mina”, fala sobre um passado maranhense e parte do imaginário do povo, através de uma peça histórica que descreve a vida de Catarina Mina, uma escrava que morava em São Luís que comprou a liberdade e passou a ser uma das personagens do folclore maranhense.

Assim, os posicionamentos das agentes a partir dos diferentes domínios culturais dos quais são produtoras, pertencentes e porta-vozes, isto é, da "cultura popular", do "artesanato", da "música" e da "culinária", são pautados pela reivindicação de uma proximidade com o "povo", da capacidade de lhe dar substância e de indicar suas necessidades, conduzindo sua delimitação e sugerindo-lhes "identidades" e características específicas — garantindo, no universo mais geral da disputa sobre a "cultura", o que é da identidade regional, a legitimidade do "popular" e sua própria legitimidade como intérpretes autorizados.

As agentes são oriundas de famílias com diferentes relações com as "expressões culturais maranhenses", demonstradas por suas inscrições em distintas ramificações desde a infância, e assumem essas referências nas suas tomadas de posição cultural e política.

Como exemplos marcantes disso, citamos Michol de Carvalho, cujo pai prestigiava a "cultura popular", além de incentivá-la a participar das festas "populares" (suas irmãs e irmão seguiram nesse caminho, assim como ela, no trânsito entre o "popular" e a universidade); Zelinda Lima, filha de um comerciante bem-sucedido, realça, das suas influências originais, que seu pai sempre patrocinava "brincadeiras" de bumba meu boi e tambor de crioula (ela própria foi "madrinha" e, assim, manteve, segundo declara, contato direto com a "cultura popular");

\footnotetext{
${ }^{5} \mathrm{O}$ termo "madrinha" é dedicado às mulheres que participam do ritual de batismo das "brincadeiras", é justamente o que marca a abertura da temporada de festividades e apresentações das mesmas. Além de cuidado e zelo, as "madrinhas" ajudam a "manter as tradições" e, sobretudo contribuem financeiramente. Por muito tempo essa ajuda era indispensável para que os "grupos" conseguissem manter seus figurinos e integrantes, já que não recebiam ainda recursos do governo do estado do Maranhão.
} 
Lenita Estrela de Sá, que também apresenta a familiaridade com a "cultura" (no caso, com o teatro) como "herdada" do pai, Cecílio de Sá, que é tido como referência do teatro amador na capital; e Déborah Baesse, que conflui as influências da mãe (Zelinda Lima) e do pai (Carlos Lima), apresentados anteriormente, ativando a vivência ligada ao "folclore" e à "cultura popular" do Maranhão para a defesa e a análise das produções artesanais do estado.

A participação efetiva de parentes, sobretudo dos pais das agentes, no âmbito cultural, garante a elas um trunfo de legitimação e propriedades específicas advindas do meio familiar, o que favorece a reprodução e conversão da legitimidade pautada na "tradição" em legitimidade pautada na "herança" desses recursos simbólicos (BOURDIEU, 2002).

É possível pensarmos na consonância entre as propriedades adquiridas por elas nesse processo de socialização familiar e a posição de legitimidade das mesmas no meio de atuação cultural. Nesse caso, recursos simbólicos e envolvimentos objetivos as tornam autorizadas, já que não se resguardam apenas nos títulos escolares, garantidos por um aparato institucional, mas aparecem como "vocacionadas", predestinadas, inclusive por "tradição familiar", a falar em nome da "cultura popular".

Isso, no feixe da pretensão de perenidade, mesmo de forma desinteressada, proporciona o tracejar de estratégias de reprodução social (BOURDIEU, 2002) demarcadas pelos laços matrimoniais das agentes, que funcionam para a manutenção da ordem de legitimidade em suas tomadas de posição sobre a "cultura", na medida em que contribuem para o reconhecimento da participação efetiva "na causa", garantindo também a manutenção dessas propriedades herdadas.

Por este motivo é interessante observar a participação efetiva dos cônjuges de algumas dessas agentes no cenário cultural. Rosa Reis casou-se com Nelson Brito, graduado em Comunicação pela Universidade Federal do Maranhão, ator e um dos fundadores do Laboratório de Experiências Artísticas (Laborarte). O Laborarte foi criado em 1972 para abrigar e formar artistas locais, e permitiu compatibilizar o discurso da luta política no período do regime militar no Maranhão com a perspectiva de difundir e divulgar a "cultura popular", com ênfase nas tradições e no folclore, relacionando-se fortemente com a cultura africana ${ }^{6}$. Deve-se apontar alguns aspectos do perfil de Nelson Brito. Ele nasceu em 1953, como destaca o Perfil cultural e artístico do Maranhão:

\footnotetext{
${ }^{6}$ Além disso, o Laboratório de Expressões Artísticas (Laborarte) converge uma influência e uma atuação vinculadas aos movimentos da igreja católica, "[...] já que esses movimentos de resistência à ditadura militar, em São Luís estão de algum modo associados à participação dos militantes em grupos de igreja e movimentos como 'Ação Católica' e 'Juventude Estudantil Católica' e muitos deles integraram justamente esses grupos de expressão artística na época” (REIS, 2014a).
} 
Nelson Brito, ator, encenador, autor, bonequeiro e dançarino, nascido em São Luís, fez parte do elenco permanente do TEMA, de 1969 a 1975. Depois passou para o LABOARTE, onde ocupou a coordenação geral de 1979 a 2001, foi presidente da Federação de Teatro do Maranhão, Tesoureiro da Confederação Nacional de Teatro Amador e Secretário da Associação Brasileira de Teatro de Bonecos. Exerceu ainda, as funções de Diretor do Teatro Arthur Azevedo e de Presidente da Fundação Municipal de Cultura de São Luís. (PERFIL CULTURAL E ARTÍSTICO DO MARANHÃO; AMARTE, 2006, p.43).

A trajetória de Nelson Brito se distingue da de Rosa Reis, sobretudo na atuação em cargos administrativos vinculados à cultura, além de no envolvimento com as "causas" e os movimentos de resistência que, acionados no decorrer da sua trajetória, garantem a sua legitimidade como intérprete do "teatro amador" e da "cultura popular". A notoriedade de Brito, após seu falecimento (em 2009), passou a ser, de certo modo, creditada à figura de Rosa Reis, que assumiu a direção do Laboratório, que administra juntamente com as filhas. Atualmente, o Laborarte é a casa delas e dos demais "chegados" de Brito, que praticam a "cultura popular" (música e dança, particularmente) e disso tiram seu sustento e notabilidade.

Em entrevista à TV Brasil, Rosa Reis define o seu meio de atuação cultural como ligado a "cultura popular" e às "tradições":

Eu sou Rosa Reis, nasci aqui na ilha de São Luís, no dia 6 de março de 1959, e desde lá eu acho que a minha vida foi sempre pautada por coisas bem interessantes, teve um período na minha vida que eu fui atleta durante muitos anos, né, fui jogadora de handebol durante muitos anos eu fiz balé clássico. Eu adorava dançar, participei de espetáculos, cheguei a viajar com o professor Reynaldo e depois eu entrei no Coral São João, e, lá no Coral, também adorei Fernando Mouchrek, toda a turma. Eu conheci lá Robert Brandão, Inácio, Claudio Pinheiro, e vários outros amigos cantores, que estão hoje ainda cantando, eu conheci lá no Coral São João. Depois do Coral São João que aí eu comecei a fazer vocais em alguns shows, fui vocal no show de Ubiratan Souza, no show de Giordano Mochel, e aí o trabalho foi crescendo com a música, e até que eu cheguei aqui no Laborarte. No Laborarte aqui na época eu participei de vários espetáculos de teatro, e desses espetáculos eu entrava com o meu canto, com a minha história, com a música, e continuei a trabalhar intensamente com o Laborarte. Eu vim pra cá em 83 e a partir daí eu comecei a trabalhar e não parei mais, aqui eu encontrei um grande parceiro que foi meu companheiro durante muitos anos, que foi Nelson Brito, que é pai das minhas filhas, e aqui a gente criou uma história, aqui dentro dessa casa, do casarão Laborarte, que já acontecia. O Laborarte foi fundado em 1972 e, a partir da década de 1980, com o Nelson à frente, a gente também começou a trabalhar mais voltados pra cultura popular. E desse trabalho com a cultura popular em 1986 a gente montou o Cacuriá de Dona Teté. Dona Teté era uma grande mestra da cultura popular, tocava tambor de crioula, era rezadeira, tocava caixa do divino, participava de festa do Tambor de Mina, e ela veio pra cá, para o Laborarte, em 1980, ensinar o pessoal a tocar caixa para um espetáculo que tava acontecendo na época que se chamava "Passos". A partir daí ela ficou e toda vez que a gente tinha uma festinha, uma brincadeira aqui no Laborarte, aí Teté fazia o cacuriá, como a gente dizia: "umbora dançar, gente..."; "umbora brincar!"; "eu tenho, eu conheço uma dança assim e tal!” E a gente começava a brincar informalmente, tanto que em várias viagens, 
encontros que nós participamos de teatro, de dança, a gente apresentava, no final da noite a gente reunia o grande público e ficava naquela brincadeira e acabava fazendo o cacuriá. $\mathrm{Na}$ época, eu dançava o cacuriá, dancei durante muitos anos o cacuriá e ao mesmo tempo em 1989 eu fiz o meu primeiro show solo, que se chamava "Cantareira". Eu realmente comecei a trabalhar minha carreira solo, tanto que em 1991 eu lancei meu primeiro vinil, depois eu fiz o segundo vinil e de lá pra cá eu fiz mais três CD’s. Fiz uma coletânea em 2010/2011 e agora no próximo ano eu tô pretendendo gravar um novo CD. Eu não sou muito de tá compondo, eu gosto mais é de cantar realmente, e hoje, atualmente, eu gosto muito é de produzir também, né. Tanto que eu tô à frente aqui do Laborarte. E o Laborarte é esse grupo que trabalha com várias manifestações, aqui a gente trabalha com o tambor de crioula, faz oficina o ano todo, trabalha com o cacuriá, também oficina o ano todo, aí tem oficina de caixeira que é só por temporadas. Então, tem o ano todo de trabalho. Então eu, ultimamente, na coordenação do Laborarte, tenho feito muita produção, até deixado mais o meu lado de trabalho de canto lá, tenho feito mais shows no Carnaval e no São João. Eu tenho trabalhado também com algumas manifestações que eu gosto muito, como o Divino Espirito Santo, como eu produzi um show no ano passado que se chama "Divinas folioas", que são as Caixeiras Régias aqui do Maranhão. Então meu trabalho tá muito enlaçado com tudo que acontece aqui no Laborarte e com as outras manifestações tradicionais que estão aqui na ilha, já são mais de vinte anos, tocando caixa, participando do cacuriá; só o Cacuriá de Teté, são trinta anos. (REIS, 2016).

As múltiplas inserções de Rosa em diferentes eixos da "cultura" são marcantes, pois ela percorreu o "teatro", as "danças clássicas" e o "canto" e se dedicou à "música". Das oito agentes, ela é uma das duas que não possui título superior; entretanto, por meio da mobilização contínua de círculos de reconhecimento (PIZZORNO, 1988), garante sua legitimidade como porta-voz da "cultura popular”. Nesse sentido, o Laborarte não deixa de ser uma instância de consagração e conservação de "memórias", auxiliando na conservação da "tradição" através da manutenção de oficinas voltadas à "cultura popular". Assim como no trabalho de sistematização feito por Michol de Carvalho, estabelecendo participação efetiva na manutenção de ciclos comemorativos ligados a um calendário da "cultura maranhense", o que observamos aqui é a demarcação de lugares, "tempos" e formas de expressão que funcionam como formas de conservação. Todo esse trabalho de seleção e manutenção em torno das "tradições" se inscreve nas bases de arbitrariedade, como construções sob o mundo social, assim como confirmam a sua inexistência como prática simplesmente vivida (NORA, 1993).

Já Arlete Nogueira Machado, cujo pai foi agente da Estação da Estrada de Ferro São Luís/Teresina e a mãe foi poetisa e cronista, destaca-se como escritora e expoente da literatura maranhense. Casou-se com Nauro Diniz Machado, que também é referência como poeta maranhense. Nauro nasceu em 2 de agosto de 1935, em São Luís, filho de Torquato Rodrigues Machado e Maria de Lourdes Diniz Machado (não foram encontrados dados quanto à ocupação e origem social dos pais). Era considerado autodidata, mas com muito conhecimento em Artes e Filosofia. Tido como um dos maiores poetas maranhenses da contemporaneidade, com uma vasta produção literária, sobretudo na década de 70, ocupou 
vários cargos administrativos, entre eles no Detran e no Emater. Com o destaque de suas obras, recebeu diversas premiações: Prêmio Sousândrade (1958, 1964); Prêmio da Associação Paulista dos Críticos de Arte (1982); e Prêmio da Academia Brasileira de Poesia (1999) (Informações reunidas em diversos sites). ${ }^{7}$

No caso de Arlete Machado e Nauro Machado, os dois estão no mesmo eixo de atuação, assim como os casais Rosa Reis e Nelson Brito, Zelinda Lima e Carlos Lima, entretanto, contam com propriedades relativamente distintas entre eles e deles com os outros casais que estariam ligados mais a "cultura popular".

Arlete Nogueira da Cruz Machado, professora universitária (UFMA), foi a primeira secretária de cultura do estado; Nauro Machado, como autodidata, conquistou reconhecimento entre seus pares, graças não somente a sua vasta produção escrita como também as suas redes de relações qualificadas (com o ex-presidente da República, José Sarney, por exemplo). Embora com níveis diferentes de reconhecimento, Arlete Machado concentra, em relação a Rosa Reis, por exemplo, uma relativa notoriedade, pelo investimento em títulos e por um volume considerável de produção literária — ou seja, naquilo que é considerado "cultura erudita". Porém, ela ainda é facilmente associada às características e ao reconhecimento do marido.

Por fim, Zelinda Lima é casada com Carlos Lima, que conquistou destaque como pesquisador e militante da "cultura popular", com atuação preponderante na Comissão de Folclore do Maranhão. O casal combina produção e administração de redes de agentes ligados à "cultura popular", sendo conhecido como o "casal da cultura popular":

Carlos Orlando Rodrigues Lima nasceu em 04 de março de 1920, em São Luís e faleceu em 2011. Filho de comerciário atuante no processamento de Arroz entre os anos de 1933 e 1936, durante muito tempo sua família acumulou recursos financeiros. Ele estudou inicialmente na Escola Modelo, e depois completou o ensino médio no Liceu Maranhense (escola que garantiu reconhecimento da formação de intelectuais na década de 40), depois de trabalhar no Comércio com o seu pai, ingressou como concursado do Banco do Brasil em 1948. Carlos Lima atribui a sua vinculação e paixão à cultura popular à [sic] Zelinda Lima, com quem se casou em 29 de junho de 1948. A partir daí Carlos Lima, passou a acompanhá-la nas "brincadeiras de bumbameu-boi", e a fazer registros fotográficos e escritos, documentando essas brincadeiras. $\mathrm{O}$ seu primeiro escrito sobre o folclore foi um folheto destinado a Empresa Maranhense de Folclore (da qual Zelinda era presidente sob a gestão de Governo de João Castelo), depois disso passa a escrever sobre história do Maranhão, reunindo, contos, poemas, artigos e boletins dedicados a Comissão Maranhense de Folclore, onde ele fez parte da reorganização juntamente com Zelinda Lima (Bumba meu boi,

\footnotetext{
${ }^{7}$ Disponíveis em:

http://gruponsgraca.blogspot.com.br/2016/06/TribLiv-i901.html ;

http://www1.folha.uol.com.br/cotidiano/2015/12/1715337-mortes-foi-ao-rio-ser-medico-e-voltou-

poeta.shtml; http://globaleditora.com.br/autores/biografia/?id=1474).
} 
1968, A festa do Divino Espírito Santo em Alcântara, 1972, História do Maranhão, 1981; Caminhos de São Luís: ruas, logradouros e prédios históricos, 2002, História do Maranhão: a monarquia, 2008). Carlos Lima, ainda destaca sua ligação com artistas maranhenses também por intermédio de Zelinda Lima, a maioria desses artistas ligados a produção do "artesanato maranhense" como Nhozinho Santos e o Sr. Lopes. Além disso, ele foi membro do Instituto Geográfico e Histórico de Maranhão e ocupou a cadeira de número 33 na Academia Maranhense de Letras. (LIMA, Carlos de, 2006, p. 55-91)

Zelinda Lima e Carlos Lima participam e divulgam seus posicionamentos no âmbito da Comissão Maranhense de Folclore - publicaram, respectivamente, 20 e 38 boletins. Ela enfoca assuntos ligados ao artesanato e à culinária, produzindo também algumas memórias e relatos de festividades da "cultura popular"; ele (já falecido) reivindicava com sucesso o posicionamento de pesquisador do "folclore" e da "cultura popular", escrevendo sobre a ritualística das manifestações populares, sobretudo no que toca ao "bumba meu boi". Sua produção e participação na "cultura popular maranhense" se perpetua pela atuação da filha, Déborah Baesse, que atribui as suas vivências da "cultura popular" à "herança" dos pais. Filha mais nova do casal, declara que os acompanhava em todas as manifestações das quais participavam e até nas reuniões da Comissão Maranhense de Folclore, o que resultou na atuação da mesma como "porta-voz" do artesanato maranhense, com a produção de boletins para a Comissão Maranhense de Folclore e do Perfil artístico e cultural do Maranhão (2006).

Porta-voz e intérprete da "cultura popular", Michol de Carvalho (já falecida) dedicou a sua atuação (escrita e política) à implementação de projetos que apresentassem uma relação com as festividades frequentadas pela agente, o que atribui à atuação e influência do pai. Sua irmã, Alba Maria Pinho de Carvalho (professora do Departamento de Ciências Sociais da Universidade Federal do Ceará), foi responsável pela produção da contracapa do livro "Perfil de cultura popular", coletânea organizada por Mundicarmo Ferretti e Zelinda Lima, que reúne publicações dos boletins da Comissão Maranhense de Folclore e que contou com o financiamento da Fundação de Amparo à Pesquisa do Maranhão (Fapema) e com o apoio da Secretaria do Estado de Cultura e Secretaria do Estado de Ciência, Tecnologia e Ensino Superior ${ }^{8}$.

Há princípios de hierarquização entre "cultura erudita" e "cultura popular", que podem ser identificados ao considerarmos os perfis dos agentes que investem em distintos modos de bens. A comparação entre as características dos membros da Academia de Letras Maranhense e as dos agentes consagrados nos perfis de cultura popular evidenciam distinções

\footnotetext{
${ }^{8}$ Sobre essa rede de relações e uma análise dessa obra como lugar de consagração dos "notáveis e intérpretes da cultura" no Maranhão, ver Grill e Reis (2016).
} 
entre os primeiros (com a preponderância de sentidos de "vocação", "herança", "predestinação", etc.) e os segundos, no que diz respeito aos recursos de legitimação e às múltiplas inserções dos agentes em instituições de domínios culturais - universidades, jornais, academia de letras, institutos de pesquisa, etc. (GRILL; REIS, 2016).

Sendo assim, nota-se de forma mais acentuada nesse "eixo da cultura popular" uma relação dessa inserção no meio cultural advinda de uma "herança familiar" e de um engajamento de todo o grupo familiar na "causa". Os critérios de legitimidade nesse universo ancoram-se, assim, tanto na ideia de uma "memória herdada" dos ascendentes, em um sentido de continuidade, como no cultivo contínuo da "tradição" em redes de sociabilidade fortemente marcadas pelo parentesco por consanguinidade, por aliança e metafórico (GRILL, 2008b).

Há, pois, uma mobilização desta "memória herdada" (POLLAK, 1992) por grande parte das agentes, assim como ocorre o resgate e a manutenção dessa "memória" na transmissão desses "bens herdados" aos seus filhos. Junto com um trabalho coletivo de reconversão e enquadramento de memória, há também um investimento individual e coletivo, em alguma medida, para a obtenção de títulos escolares e outras qualificações que ratifiquem essa "herança”, essa "vocação", nesse duplo investimento dos agentes — como nos casos de Zelinda Lima, por meio do trabalho também de afirmação e resgaste da "cultura" feito por Déborah Baesse; de Rosa Reis e de suas filhas, que possuem forte atuação na gestão do Laborarte; de Michol de Carvalho com seu pai e irmãos; e, por fim, de Arlete Nogueira Machado, cujo filho é cineasta e possui forte influência no cenário cinematográfico de São Luís, assumindo a administração do Cine Praia Grande e do Cine Lume.

Rosa Reis e suas filhas buscam afirmar a dança que é associada a Dona Teté (considerada por elas mãe e avó “de consideração”). Déborah Baesse, por seu turno, escreve sobre artesanato (fundindo saberes que os pais lhe transmitiram) e se inscreve em círculos de reconhecimento de ativistas culturais e políticos, que permitiram seu acesso a cargos públicos. Por fim, Arlete Nogueira dispõe de atributos culturais adquiridos e herdados do meio familiar e conjuntamente com Nauro Machado, que a alçaram a postos de relevo no âmbito das políticas governamentais ligadas à cultura.

Percebe-se, por intermédio das informações biográficas que conseguimos reunir das agentes, que, simultaneamente ao resgate de uma "memória" e à conversão de uma memória individual ou familiar em memória coletiva (POLLAK, 1992, 1989), elas mobilizam suas experiências pessoais e suas vivências familiares como trunfos biográficos que as autorizam a interpretar as diferentes manifestações culturais que caracterizam a identidade regional. Juntamente a isso, há uma teia de relações sociais interdependentes, círculos de reconhecimento 
que, numa espécie de intercruzamento, combinam propriedades sociais, "vocação", "tradição", "heranças", "títulos escolares" e inserções em diferentes instituições vinculadas à cultura. Por esses meios, credenciam-se como "porta-vozes da cultura" pela produção que reúnem, principalmente em forma de livros e textos, e pelos cargos de administração ligados à gestão da cultura em governos estaduais e municipais.

Infelizmente, a escassez de dados inviabilizou a análise detida das origens sociais de duas das agentes (Kátia Bógea e Rosilan Garrido). Porém, cabe sublinhar que elas conquistaram notabilidade nas esferas em que atuaram: ocuparam cargos administrativos e obtiveram reconhecimento como porta-vozes das "artes plásticas" e do "patrimônio" maranhense.

É válido notar o lugar dessas informações de origem social para as agentes acima mencionadas. Das oito agentes em questão, somente as duas não possuem páginas virtuais pessoais disponíveis. As informações coletadas a seu respeito estão em sites como a Plataforma Lattes (Rosilan Garrido) e o perfil do Instituto de Patrimônio Histórico e Artístico Nacional (Kátia Bogéa), o que pode indicar a forma como se apresentam e se afirmam nos domínios culturais: a partir de perfis mais técnicos, respaldados em títulos escolares e ocupação de cargos.

Elementos da relação de Kátia Bógea com o "patrimônio" e, consequentemente, com a sua concepção em torno da "cultura maranhense" podem ser encontrados na entrevista disponível na internet que concedeu ao programa televisivo "Avesso”, na TV Guará (emissora local), quando a agente é convidada a falar sobre o título de Patrimônio Histórico recebido por São Luís e o papel do Iphan nessa manutenção do "patrimônio":

A sociedade brasileira entendeu que era importante pra ela ter sua identidade cultural. O Brasil é um continente, é um país continente, e ele tem uma coisa extraordinária: a formação étnica, diversas etnias, e isso deu essa identidade étnica incrível, que difere o Brasil dos outros países. Pra nós a sociedade entendeu que é importante a preservação dessa identidade e dessa diversidade. Isso é feito através do patrimônio. O patrimônio é um ato político porque é uma escolha, a gente trabalha com memória. Você pode lembrar tudo? Você deve lembrar tudo? Não. Você faz escolhas. Daquilo que é importante, daquilo que tem um significado e precisa ser protegido, [...] ser preservado. Então, a nossa missão constitucional, legal, é proteger essa memória. Se aquilo tem um instrumento jurídico, seja um tombamento pro patrimônio material ou um registro pro patrimônio imaterial, ou a chancela de uma paisagem cultural, o Iphan tem uma legislação que tem que seguir. A sociedade entendeu que aquilo tem que ser protegido, o Ministério Público fiscaliza a nossa atuação pra que esse direito difuso que pertence a todos, essa memória, seja preservada. Então, não é dizer não, né? A gente trabalha com diretrizes, com normas, com legislações que precisam ser observadas. Orientamos tecnicamente a todas as intervenções, mas [...] muitas vezes os projetos são projetos equivocados, são projetos de má qualidade, são projetos que não atendem nem ao interesse do desenvolvimento, nem ao interesse da preservação, que podem, sim, se conciliar! Os países mais desenvolvidos já fazem isso com a maior tranquilidade. Veja, o ministério mais importante da França é o Ministério do Turismo, o Ministério da Cultura, por quê? Porque isso é o que gera renda, desenvolvimento, e agrega valor. A Espanha tá fazendo isso como ninguém, quer dizer 
[...] o Brasil só precisa caminhar muito, avançar muito pra compreender isso. (BÓGEA, 2012).

Kátia Santos Bogéa nasceu em 12 de junho de 1961, em Lagartos (Sergipe). Casada e mãe de dois filhos, recebeu o título de cidadã ludovicense pela Câmara de vereadores de São Luís em 2015. Graduada em História (UFMA) e com especialização em Historiografia Regional e Nacional (USP), atuante no Instituto do Patrimônio Histórico e Artístico Nacional no Maranhão, ocupou a Superintendência Regional por 12 anos (2003-2015), assumindo, em 2016, a Superintendência do Instituto do Patrimônio Histórico e Artístico.

É interessante perceber a vinculação da agente com órgãos que tendem ao amparo burocrático, sugerindo o cumprimento de normas e pautando-se numa certa impessoalidade, o que reflete um posicionamento da agente. A autodescrição da instituição do Instituto do Patrimônio Histórico e Artístico (Iphan), por exemplo, já aponta para o seu "papel” e para os fluxos e regulações com outras instituições. Assim, a ocupação dessas posições vem acompanhada de perspectivas que contribuem para a difusão da "cultura patrimonial" como causa legítima, incluindo discursos sobre a necessidade da inclusão de uma "educação patrimonial".

O Iphan responde pela conservação, salvaguarda e monitoramento dos bens culturais brasileiros inscritos na Lista do Patrimônio Mundial e na Lista do Patrimônio Cultural Imaterial da Humanidade, conforme convenções da Unesco, respectivamente a Convenção do Patrimônio Mundial de 1972 e a Convenção do Patrimônio Cultual Imaterial de 2003. (Disponível em: http://portal.iphan.gov.br/pagina/detalhes/872, acessado em: 14.04.2017).

O posicionamento de Kátia Bogéa evidencia a preocupação em estabelecer e resguardar através do "patrimônio" uma "identidade nacional”, própria do cargo que ocupa. Ela segue padrões de "normalização" sugeridos pelo Iphan, como órgão que garante e certifica a sua legitimidade, para falar em "nome do patrimônio" e para selecioná-lo. Agindo também sob o requisito da especialização necessária, o fato de não ser maranhense a inscreve numa dinâmica distinta de circulação de ideias, assim como a diferencia das outras agentes, já que não é alimentada diretamente por círculos de reconhecimento baseados em relações pessoais.

\section{CONSIDERAÇÕES FINAIS}

As propriedades sociais com as quais as agentes contam e as relações que elas acumularam ao longo do tempo viabilizam a ocupação de posições destacadas e distintas 
relativas à "cultura". Elas adquirem o reconhecimento legítimo por meio de suas trajetórias e vínculos e, assim, incorporam e reconhecem também expressões da "cultura maranhense" como parte de suas vidas. Por meio disso, tornaram-se notáveis em níveis variados, constituindo-se como porta-vozes e intérpretes da "cultura maranhense", auxiliando, então, na edificação de elementos da "cultura" como temas legítimos, inclusive para a produção de políticas públicas.

É interessante observar que, se nesses domínios culturais há uma prevalência de mulheres ocupando posições de relativo destaque, esses perfis e formas de atuação não são tão preponderantes em todos os universos culturais. Silva (2009), por exemplo, estudou especificamente as escritoras maranhenses pertencentes à Academia Maranhense de Letras. Ele identificou a baixa presença de mulheres nesse segmento da elite cultural ligada à cultura "erudita", o que nos leva a pensar sobre a correspondência entre as posições dominadas nas relações de gênero e as concepções de cultura em concorrência no estado.

Ainda, mesmo que no universo ora analisado exista tal destaque para a presença feminina, observamos que o lugar de intervenção, o escopo da atuação e o reconhecimento adquirido são claramente restringidos por condicionantes de gênero. As mulheres em questão se notabilizam, pois, condensando atributos que as fazem "mulheres", ou seja, desempenhando papeis socialmente predefinidos, esperados. Há variações entre elas, por exemplo, no que diz respeito à conquista de reconhecimento mais independente da vinculação com os maridos, e isso está relacionado às origens sociais e ao grau de escolarização de cada uma delas. Mas, para todas, assim como para todos, as redes de relações são imprescindíveis para as suas oportunidades de sucesso e trânsito. Assim, aplicam-se, nesse universo, princípios ajustados de "reprodução social, faccionalismo e cadeias de reciprocidades", persistentes nos domínios políticos e no espaço social como um todo (GRILL, 2014, p. 242).

No exame de um universo mais amplo - tomando-se como base o Perfil cultural e artístico do Maranhão —, que abarcou outros interpretes da "cultura" em eixos diferentes de atuação, o especialista chamado para falar de Literatura foi Jomar Moraes, para o patrimônio/a arquitetura foi Luiz Phelipe de Carvalho Castro Andrés (não Katia Bogéa), para as Artes Cênicas foi Tácito Freire Borralho (não Lenita Estrela de Sá), e para a música foi Josias Sobrinho (não Rosa Reis), o que pode nos ajudar a pensar na hierarquia das temáticas e dos seus intérpretes autorizados. No último caso citado, de Rosa Reis/Josias Sobrinho, realça-se a preferência por um herdeiro direto do Laborarte, Josias Sobrinho (que se trata de um dos 
integrantes originais do Laboratório e porta-voz do que chamaram de Música Popular Maranhense).

Dos quatro agentes, três nasceram no interior do Maranhão (Cajari, Primeira Cruz e Guimarães), com exceção de Luiz Phelipe Andrés, que nasceu em Juiz de Fora (Minas Gerais), chegando a São Luís na década de 1990.

Os agentes têm origem social nas classes média e baixa (as profissões dos pais encontradas foram: comerciante, professor e médico). Apenas um deles, Josias Sobrinho, não possui uma formação superior, sendo que os demais condensam uma forte formação acadêmica (Direito, Engenharia e Teologia). Chegam a assumir vários cargos administrativos vinculados à "cultura", como superintendente do Iphan (Maranhão), secretário de Cultura do Estado, presidente do Conselho de Cultura do Estado, diretor do Departamento de Cultura do Estado, entre outros.

Os agentes acumulam títulos e inserções em cargos administrativos em órgãos voltados para a cultura, assim como uma rede de relações que lhes garante reconhecimento e legitimidade para falar sobre tal assunto. Nesses aspectos, eles não se distinguem das agentes analisadas; porém, dentre os eixos destacados pelo Perfil cultural, somente três foram comentados por mulheres: a Cultura Popular (Michol de Carvalho), as Artes Plásticas (Rosilan Garrido), a Culinária (Zelinda Lima) e o Artesanato (Déborah Baesse).

As áreas de expressão femininas, nesse caso, vão ao encontro da ideia de áreas de atuação que devem ser aferidas com mais "sensibilidade", "cuidado" e "apreço", como as manualidades, que por muito tempo foram consideradas dotes e parte da educação das mulheres. Isso se reflete nas Artes Plásticas, no Artesanato e na Culinária.

A disposição e os posicionamentos das mulheres em questão sugerem uma divisão do trabalho fundamentada na divisão do trabalho sexual, num sistema de oposições entre o homem e a mulher e nos papéis socialmente constituídos e desenvolvidos por eles (BOURDIEU, 2002), o que impõe um limite, um espaço possível de movimentação e mobilização, para essas mulheres, em relação aos agentes homens, imersos no domínio cultural.

Tais demarcações de espaço podem ser analisadas no processo de construção e manutenção dos "Panteões da cultura maranhense", na qual a participação das mulheres se atém à posição de enaltecedoras de outros agentes, que são na maioria homens. Assim, a produção dos boletins da Comissão Maranhense de Folclore se debruça mais nas biografias de homens atuantes na cultura, com a característica de mulheres biografarem com muito mais frequência do que são biografadas (GRILL; REIS, 2016). 
Para o universo que analisamos, podemos notar, de forma ainda preliminar, que ao longo de suas biografias estas mulheres acumulam propriedades que as legitimam como representantes dos meios em que atuam. Sua escolarização, os meios familiares e os vínculos afetivos e políticos que estabelecem, principalmente, estão na base da ocupação de cargos políticos administrativos vinculados à "cultura" e da produção de bens simbólicos variados. Porém, elas garantem um prestígio relativo, tanto em relação aos seus homólogos quanto em relação aos seus esposos, que na sua maioria atuam com elas nas causas da "cultura" no/do Maranhão.

A análise dos dados biográficos dessas oito agentes reconhecidas como intérpretes do Maranhão permitiu a compreensão inicial dos processos de definição das concepções de "cultura" no e do Maranhão, que é dada e cultivada como essência, mas que explicita disputas e concorrências pela di-visão da realidade social, tornando "possível verificar as condições de afirmação e disputas em torno tanto do papel político como de intelectual assim como os usos possíveis do reconhecimento que seus porta-vozes desfrutam e no trabalho de categorização" (REIS, 2014b, p. 25).

Nesta linha, observam-se os posicionamentos e os atributos distintivos que consagram representantes, que passam a ser produtoras de representações. Tais elementos se combinam para gestar uma ideia de "vocação" para a "cultura", garantindo o reconhecimento e refletindo na atuação e ocupação dessas agentes de cargos ligados à "cultura”, o que reafirma também a cadeia de interdependência existente entre as agentes e o peso da gama de relações constituídas no decorrer de suas vidas.

No desdobramento dessa discussão, pretendemos fazer uma comparação mais sistemática entre elas, suas propriedades sociais e profissionais, suas carreiras, períodos de atuação e produção cultural, para examinar as posições que ocupam umas em relação às outras e os condicionantes das suas tomadas de posição.

\section{REFERÊNCIAS}

ANDRÉS, Luis Phelipe de Carvalho Castro[et al.]; coordenação, Maria de Fátima Reis Caracas, Rodrigo José Bugarin Caracas. Perfil cultural e artístico do Maranhão. São Luís: AMARTE, 2006.

BAESSE, D. de C. Currículo do sistema currículo Lattes. Disponível em: $<$ http://buscatextual.cnpq.br/buscatextual/visualizacv.do?id=K4451845T0>. Acessado em 11.04.2017. 
BÓGEA, K. Entrevista. TV Guará, 3 abr. 2012.

BOURDIEU, P. Stratégies de reproduction et modes de domination. Actes de recherche en sciences sociales, Paris, v. 105, n. 1, 1994.

A ilusão biográfica. In: . Razões práticas: sobre a teoria da ação. Campinas: Papirus, 1996, p. 74-82.

. "A identidade e a representação. Elementos para uma reflexão crítica sobre a ideia de região". In: Poder Simbólico. Lisboa: Difel, 1989.

. Descrever e prescrever: as condições de possibilidade e os limites da eficácia política. In: _. O que falar quer dizer: a economia das trocas linguísticas. São Paulo: EDUSP, 2008.

. A dominação masculina. Rio de Janeiro: Bertrand Brasil, 2002.

Os usos do povo. In: . Coisas ditas. São Paulo: Brasiliense, 2004.

. A força da representação. In: O que falar quer dizer: a economia das trocas linguísticas. São Paulo: EDUSP, 2011a, p. 193-216.

O espírito de família. In: Razões práticas: sobre a teoria da ação. Campinas: Papirus, 2011b.

BRUBAKER, E.; COOPER, F. Mas allá de "identidade”. 2013. Disponível em: $<$ http://comunicacionycultura.sociales.uba.ar/files/2013/Brubaker-Cooper-espanol.pdf>. Acesso em: 8 oct. 2016.

CORADINI, O. L.; REIS, E. T. dos. Transações culturais, intelectuais e as ciências sociais. Revista Pós - Ciências Sociais, n. 17, p. 09-17, 2012.

ELIAS, N. The Changing Balance of Power Between the Sexes - a Process-Sociological Study: the Example of the Ancient Roman State. Theory, Culture \& Society, London, v. 4, n. 2 , p. 287-316, 1987.

GRILL, I. G. Heranças políticas no Rio Grande do Sul. São Luís: EDUFMA, 2008.

- A especialização política no Maranhão: padrões de seleção, níveis de disputas e interdependências. In: REIS, E. T. dos; GRILL, I. G. Estudos de elites políticas e culturais. São Luís: EDUFMA, 2014.

GRILL, I. G.; REIS, E. T. dos. O que escrever quer dizer na política? Carreiras políticas e gêneros de produção escrita. Revista Pós - Ciências Sociais, São Luís, n. 17, p. 101-102, 2012.

Elites parlamentares e a dupla arte de representar: intersecções entre "política" e "cultura" no Brasil. Rio de Janeiro: FGV Editora, 2016a. 
Intérpretes e notáveis da literatura e da cultura popular do Maranhão: reflexões e pesquisas recentes em arte e cultura nas sociedades contemporâneas. Trabalho apresentado no 40. Encontro Anual da ANPOCS, Caxambu, Minas Gerais, 2016 b.

LENCLUD, G. A tradição não é mais o que era... Sobre as noções de tradição e de sociedade tradicional em etnologia. História, histórias, Brasília, v.1, n.1, 2013.

LIMA, Carlos de. Depoimento. In: Memória de Velhos, depoimentos: uma contribuição à memória oral da cultura popular maranhense, vol.6. São Luís: SECMA/CMF,2006, p.55-91.

LIMA, Zelinda. Depoimento. In: Memória de Velhos, depoimentos: uma contribuição à memória oral da cultura popular maranhense, vol.6. São Luís: SECMA/CMF,2006, p. 219-307.

NORA, P. Entre memória e história: a problemática dos lugares. Projeto História, São Paulo, v. 10, p.7-28, 1993.

O IPHAN. Disponível em: <http://portal.iphan.gov.br/pagina/detalhes/872>. Acessado em: 14.04.2017.

PIZZORNO, Alessandro. Algum tipo diferente de diferença: uma crítica das teorias da escolha racional. In. Foxley, A.(et ali). Desenvolvimento e Política. São Paulo: Vértice,1988.

POLLAK, M. Memória, esquecimento e silêncio. Estudos Históricos, Rio de Janeiro, n. 3, 1989.

. Memória e identidade social. Estudos Históricos, Rio de Janeiro, n. 3, 1992.

REIS, E. T. dos. Em nome da "cultura": porta-vozes, mediação e referenciais de políticas públicas no Maranhão. Sociedade e Estado, Brasília, v. 25, n. 3, p. 499-523, 2010.

. "Fé" nos engajamentos políticos e culturais no Maranhão. In: REIS, E. T. dos; GRILL, I. G. Estudos de elites políticas e culturais. São Luís: EDUFMA, 2014a.

O trabalho de construção de um "perfil artístico e cultural do Maranhão". In: REIS, E. T. dos; GRILL, I. G. Estudos de elites políticas e culturais. São Luís: EDUFMA, $2014 \mathrm{~b}$.

. Um tipo diferente de diferença na elite política: perfis políticos e inserções culturais de parlamentares brasileiras. Cadernos Pagu, Campinas, n. 43, p 233-263, 2014c.

REIS, E. T.; GRILL, I. G. Para um estudo de imbricações entre domínios políticos e intelectuais. In: Estudos de elites políticas e culturais. São Luís: EDUFMA, 2014.

REIS, R. Entrevista. TV Brasil, 23 jun. 2016.

SÁ, L. E. de. Sobre a Autora. Disponível em: http://estreladesa.com.br/sobre-a-autora. Acessado em 07.04.2017.

SCOTT, J. Gênero: uma categoria útil de análise histórica. Educação e Realidade, Porto Alegre v. $16, \quad$ n. $2, \quad$ p. 5-22, 1995. Disponível em: 
http://seer.ufrgs.br/index.php/educacaoerealidade/article/view/71721/40667. Acessado em: 10.01.2017.

SILVA, Renato Kerly. Academia Maranhense de Letras: Produção literária e reconhecimento de Escritoras maranhenses. São Luís: Dissertação de Mestrado em Ciências Sociais.

PPGCSOC, 2009.

SIMIONI, A. P. C. Profissão artista: pintoras e escultoras acadêmicas brasileiras. São Paulo: FAPESP, 2008. 360 p. 